\author{
Ljulj, Andrija \\ Slapničar, Vedran \\ Grubišić, Izvor
}

http://dx.doi.org/10.21278/brod72105

ISSN 0007-215X

eISSN 1845-5859

\title{
CURRENT APPROACHES TO THE MANAGEMENT OF NAVAL SHIPBUILDING PROJECTS
}

UDC 623.82:005.8

Professional paper

\begin{abstract}
Summary
The paper deals with the analysis of development and trends in the field of management of naval shipbuilding projects. The introductory part gives an overview of project management in the defense sector as well as in the naval shipbuilding sector. The analysis of naval shipbuilding project management is done through consideration of four criteria: naval strategy and long-term planning, shipbuilding industrial base, workforce, and project management organization. Due to limited resources, five countries were selected: the United States of America (USA), the United Kingdom (GBR), Australia (AUS), New Zealand (NZL), and Croatia (HRV). After individual countries have been analysed, synthesis and comparison of results were presented in tabular form. The conclusion is based on global trends in this area, how the naval shipbuilding project management in the Republic of Croatia is harmonized with them, and recommendations for improving the process of managing naval projects in the Republic of Croatia. The scientific contribution of the paper is in defining a systematic approach to managing naval shipbuilding projects that could serve as a generic model on which the future organization and management processes of naval shipbuilding projects in the Republic of Croatia and other maritime countries, that are comparable in economic strength and defense needs, may be founded.
\end{abstract}

Key words: naval shipbuilding project management; strategic planning; industrial base; workforce

\section{Introduction}

Effective project management is crucial for the success of any organization, which is why it is given special attention. Project management is directly related to programs (several different projects) from a portfolio that comprises the complete operations of individual organizations. Project management is important to both civilian and military organizations and in this respect, there are many similarities between them such as project initiation, allocation of resources, and monitoring of project execution. In the defense and security organization, projects introduce new capabilities such as a new weapon system, a communication system, computerization of business processes, new or improved tactical and technical procedures, 
organizational changes, development of strategic documents, etc. In the navy, the most important projects are related to the design, construction, and commissioning of new ships, which are the basic tool for the functioning and implementation of naval tasks. This paper will focus on such naval projects. They are complex enough and interdisciplinary because they include various professional fields such as naval architecture, shipbuilding, mechanical and electrical engineering, electronics, computing, communications, etc. For the elaboration of the topic, the five countries were analysed: the United States of America (USA), the United Kingdom (GBR), Australia (AUS), New Zealand (NZL), and Croatia (HRV). The analysis is done through consideration of four criteria: naval strategy and long-term planning, shipbuilding industrial base, workforce, and project management organization.

Overview of project management issues in selected representative countries is given in the sequel:

- Project management concepts, methods, and organization become how military organizations seek to harness and integrate scientific and technological advances in the procurement of complex weapon systems whose design, development, and production process can take years [1]. The article describes the connection between the procurement process and project management in the US Department of Defense through the implementation of the External Acquisition Research Program (EARP) and emphasizes the need to introduce changes and improvements in the procurement system through the implementation of necessary research.

- Paper [2] presents an alternative model of defense program management to achieve a more organized defense resource management.

- In [3] an introduction to the U.S. Department of Defense's procurement management system with a focus on general management policies and procedures is provided.

- Handbook [4] guides current and future US Department of Defense personnel participating in joint procurement programs.

- Document [5] describes the process of procuring military weapons and equipment in the U.S. Department of Defense with a focus on presenting reforms that would increase its effectiveness.

- Paper [6] provides an analysis and review of the literature on the causes of delays in the procurement of military weapons and equipment and the challenges faced by project managers in the field of schedule management, which is related to all other aspects of procurement.

- Document [7] represents a long-term development strategy for the Royal Navy. Given that this is a projection into the distant future, the strategy defines the transformation of the system of procurement of naval weapons and equipment to meet the requirements.

- In [8] there are analyses of the capability of the shipbuilding industrial base in the United Kingdom to meet the demands of current and future Ministry of Defence (MOD) programs.

- Discussion paper [9] provides an overview of the workforce needed in AUS naval shipbuilding and where it will be procured in the context of the huge investment in naval shipbuilding of A $\$ 90$ billion under the long-term plan.

- Publication [10] gives an analysis developed in support of the development of an Australian Navy shipbuilding plan that linked naval requirements to capabilities, available resources, and the future size of shipbuilding capacity for the construction and maintenance of naval ships.

- Document [11] presents a Naval Shipbuilding Plan that lays the foundations for building a strong, self-sustaining, and innovative Australian Naval Shipbuilding that has not been undertaken since World War II. The plan envisions a reconstruction and development of the Navy that will be in support of Australia's strategic and economic goals for decades to come. 
- Document [12] describes defense policies and strategies related to the use of the Navy and the vision of their future development in the NZL.

- Paper [13] gives an example of managing the project of acquisition of a coastal patrol ship for the needs of the Croatian Navy (Coast Guard), ways of managing risks, and other challenges encountered by the project team during the design and construction of the ship.

\section{Management of naval projects in the representative countries}

\subsection{United States of America - USA}

In changed conditions, when the new world becomes more multipolar US Navy has the intent to keep a superpower position as it is stated in [14]. In the paragraph about the security environment, it says: "It has been decades since we last competed for sea control, sea lines of communication, access to world markets, and diplomatic partnerships. Much has changed since we last competed. We will adapt to this reality and respond with urgency."

As it is well known, US orientation towards oceans is the most important pillar of their foreign and security policy. It means to have a strong and modern Navy that during peace will serve as soft diplomacy and as necessary during crisis and conflicts will be used to strike and defeat adversaries. Following the above statements, the US spends a huge amount of money to develop and maintain such a naval force.

Following [15], currently, the US Navy has 299 ships and a long-term development plan calls for 355 ships. Toward that goal, the Navy would buy 304 ships over the 2020-2049 period: 247 combat ships and 57 combat logistics and support ships. Congressional Budget Office estimates that buying the new ships specified in the 2020 plan would cost 865 billion $\$$ over 30 years or an average of 28.8 billion $\$$ per year.

To facilitate program and service acquisition there are generally support structures showed in Fig. 1 taken from [16].

It can be concluded that in the US MoD exist a strong project management structure in support of the development and execution of important naval projects. The lowest level is executive program teams that are in support of program managers and they can be organized functionally or by work breakdown structure. Above them are integrated project teams and overarching project teams that focus on a particular topic such as cost/performance, program baseline, acquisition strategy, test and evaluation, or contracting and overall review and oversight of programs. The highest level is the Defense Acquisition Board / Milestone Decision Authority. All details about the US acquisition process and project management can be seen in [5] and [16]. To achieve the set goals of the projected 355 ships it is necessary to have an adequate industrial base and trained workforce in shipbuilding. Currently, the US has seven shipyards that are involved in building naval ships, and two of them are government-owned. By [15] the U.S. shipbuilding industrial base has some unused capacity to take on increased Navy shipbuilding work, particularly for certain kinds of surface ships, and its capacity could be increased further over time to support higher Navy shipbuilding rates. Time and investment would be needed to hire and train additional workers and increase production facilities at shipyards and supplier firms, particularly for supporting higher rates of submarine production. It is assessed that workforce across the shipyards would need to increase up to 40 percent over the next 10 years or up to 50000 people, and 4 billion $\$$ would need to be invested in the shipyard infrastructure. 


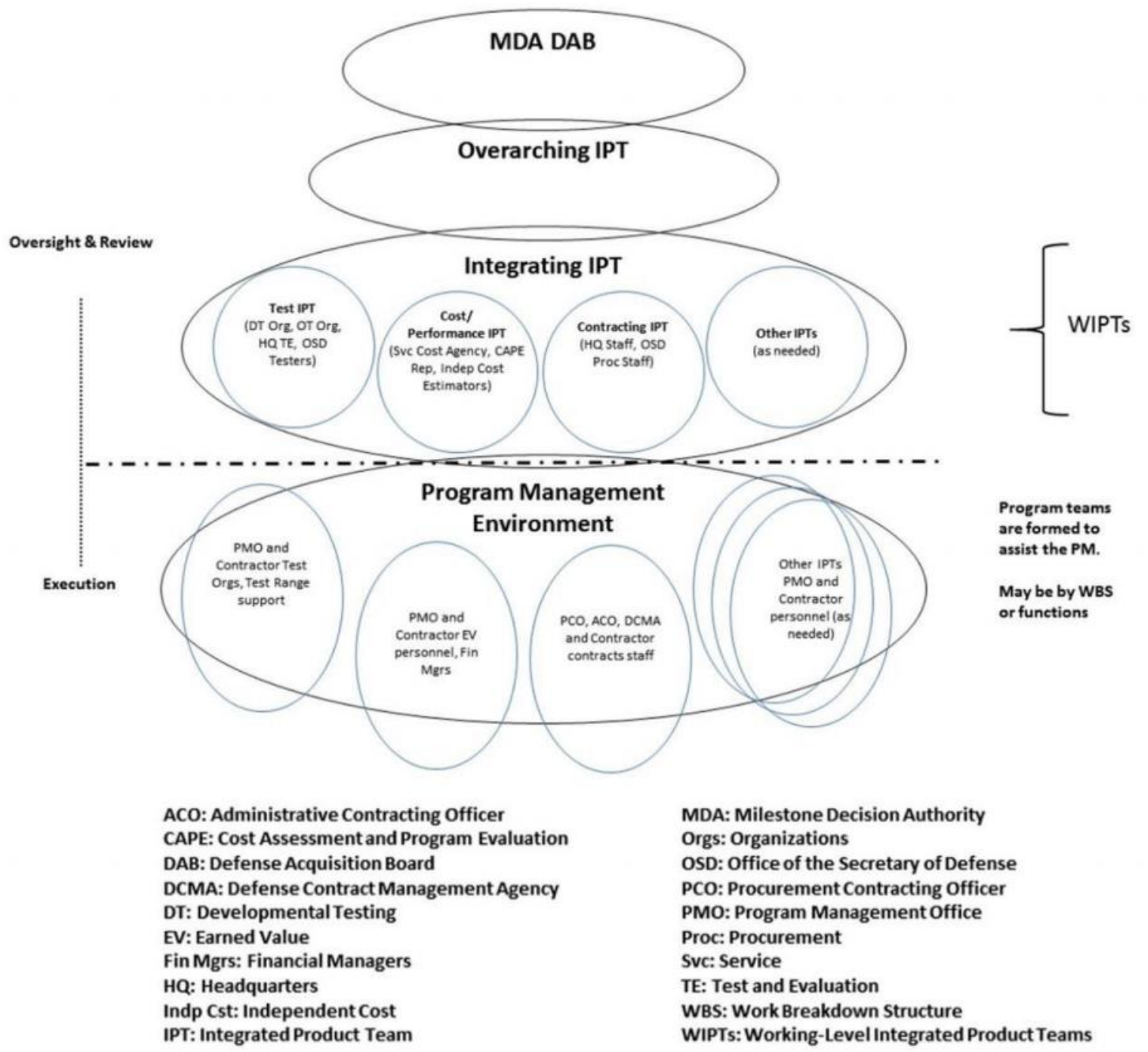

Fig. 1 US Defense Acquisition Support Structure, [16]

Document [15] provides a summary of some useful lessons learned from naval shipbuilding acquisition processes such as:

- At the outset, get the operational requirements for the program right.

- Impose cost discipline upfront. Use realistic price estimates, and consider not only development and procurement costs but life-cycle operation and support costs.

- Employ competition where possible in the awarding of design and construction contracts.

- Use a contract type that is appropriate for the amount of risk involved, and structure its terms to align incentives with desired outcomes.

- Minimize design/construction concurrency by developing the design to a high level of completion before starting construction and creating an effective process for mitigating the effect of changes in requirements and consequent design changes during construction.

- Properly supervise construction work. Maintain an adequate number of properly trained supervisors of shipbuilding personnel.

- Provide stability for the industry, in part by using, where possible, multiyear procurement or block buy contracting.

- Maintain a capable government acquisition workforce that understands what it is buying, as well as the above points. 


\subsection{United Kingdom - GBR}

As an island nation, the UK throughout history leaned on its Royal Navy that was a provider of security and prosperity. In 2017 UK MoD developed the National Shipbuilding Strategy: The Future of Naval Shipbuilding in the UK [7]. The strategy commits the UK to increase and strengthen the Royal Navy that will ensure its national interests at home and abroad. The goal of the Strategy was to lay the foundation for a modern and efficient sector capable of meeting the country's future defense and security needs. The Strategy also gives a detailed plan for delivering its vision which will equip the Royal Navy with more modern ships and the development of a strong shipbuilding enterprise. The UK has a plan to spend 63 billion $£$ for Royal Navy development which includes the acquisition of frigate Types 26 and Types 31e. Also, the Strategy delineates a 30 year Royal Navy shipbuilding Master Plan that will cover the number and type of needed ships.

Following [7] the UK will work in partnership with industry and provide the support they need. The aim is to improve public procurement, increase trade, and drive innovation in the maritime sector while paying close attention to the demands that this places on skills and the workforce. A Maritime Enterprise Working Group was established to undertake a long-term program of improvement. The main priorities of this engagement would be to develop a collective in-depth understanding of the opportunity for the sector and improvement of productivity. In 2016 the Government announced 13 million $£$ of funding support that will provide strong and sustained leadership to raise productivity across the business community through management training by specialized productivity academies across the country. As a result of this initiative, the shipyards adopted some advanced manufacturing process technology to improve productivity and reduce costs.

The strategy also recognized the need to incorporate emerging technologies that have dual applications within the defense and civil sector. To support naval shipbuilding the UK plans to increase investment in research and development. UK Government will continue to work with industry to improve the whole process of designs, building, and maintaining the Royal Navy Fleet.

For reasons of national security, all Royal Navy warships (destroyers, frigates, and aircraft carriers) will continue to have a UK-owned design, and, will be built and integrated in the UK. The acquisition of naval ships will be through competition among UK shipyards. But international partners will be encouraged to work with UK shipyards and other providers to produce the best possible commercial solution. All other naval ships should be subject to open competition. Integration of sensitive UK-specific systems will be done in the UK, where possible after competition between UK providers [7].

It is assessed that direct and indirect quantifiable value-added of the Royal Navy's shipbuilding program is at least 1.5 billion $£$ annually to the UK economy, and it supports up to 25,000 jobs. There are several activities in place across the whole UK projected to support the development of an adequate workforce with appropriate skills. The number of apprenticeships and graduates in the shipbuilding industry and supply chain is primarily a matter for the companies concerned. To remain competitive and minimize their cost base, the Industry will determine what skills are needed to deliver programs, and tune their workforce accordingly. UK Government supports the establishment of Institutes of Technology which will deliver the higher-level technical skills that the workforce needs, and invest in other initiatives related to technical education and practical skills in shipbuilding.

Following [7] UK Government introduced changes that will transform public sector processes for ship procurements. They created a new governance structure to ensure a clear line of sight between decision-makers and the teams which deliver the ship procurement projects (Fig. 2). For every new project, the Client Board will make sure that the naval capability requirement, support strategy, funding envelope are matured and agreed upon far earlier in the 
procurement process. The new structure will improve the management of, and resource provision for, the risk to provide ship procurement deliver against the set time, cost, and performance. The Client Board will ensure the project teams deliver the ships the Royal Navy requires within the agreed capital deliveries. This will enable high-level authoritative decisionmaking is at the heart of the National Shipbuilding Strategy governance structure. The Client Board will be supported by the shipbuilding Project Teams which will act as portfolio managers; providing one set of Management Information to senior decision-makers. The shipbuilding strategy Project Team will also monitor and provide advice on the industrial capacity, in the shipyards and supply chain. This will allow portfolio-level decisions to be made based on a holistic view of how the Industry is configured, including their plans. The structure includes a series of new posts and teams which will include individuals with experience in commercial shipbuilding. Project Teams will be empowered to deliver their projects within a defined time, cost, and performance, reporting progress directly to the Client Board. The Royal Navy and Defence Equipment and Support will bring additional independent and expert advice into the portfolio. They will appoint project directors from the private sector to bring in further project management, commercial and technical experience where needed.

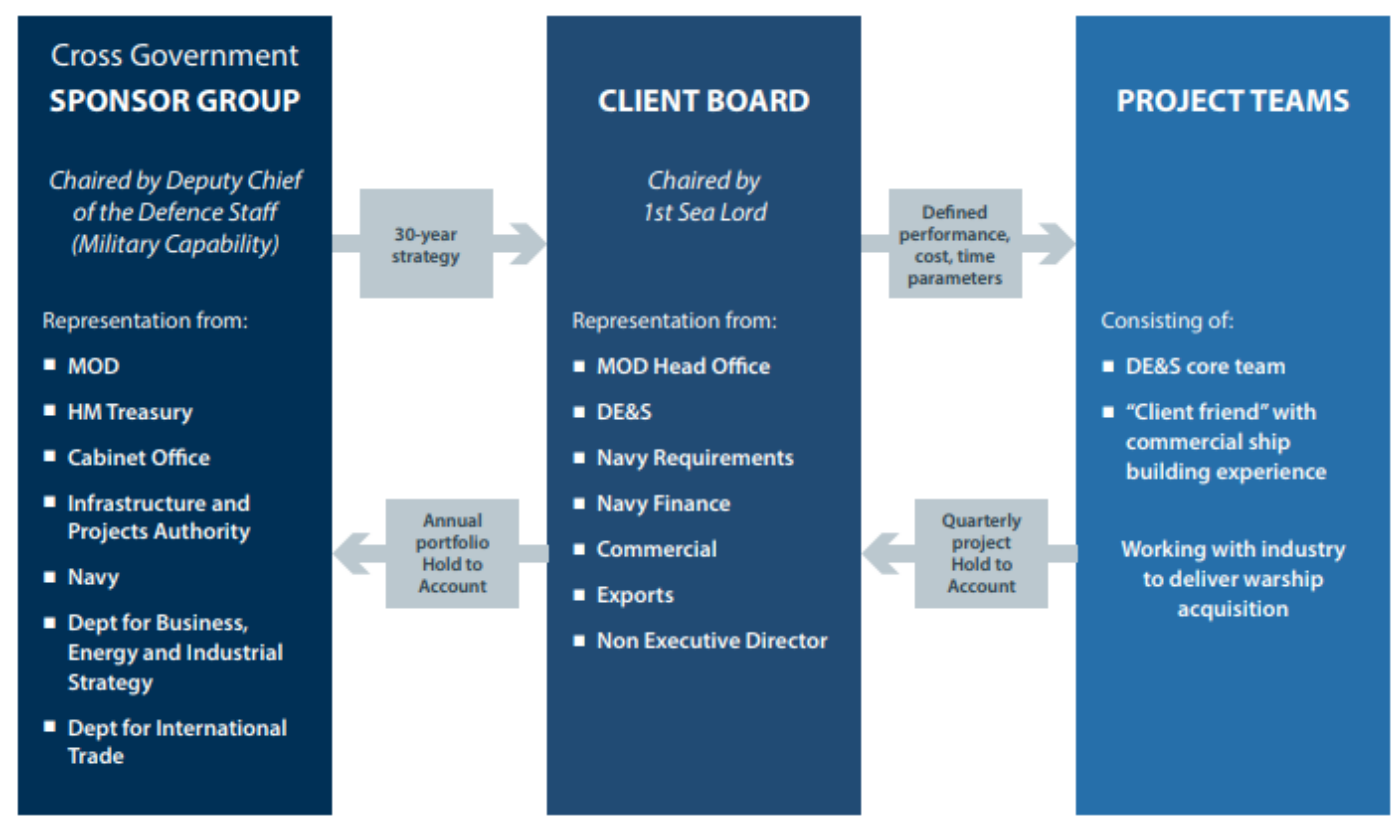

Fig. 2 New UK shipbuilding governance structure, [7]

In [17] a competition to build three Fleet Solid Support warships - which will launch in Spring 2021 - will help revitalise British shipbuilding by requiring a significant proportion of the build and assembly work to be carried out in the UK.

\subsection{Australia - AUS}

The Federal Government has an ambitious plan to rebuild the Australian naval fleet in the next long-term period. The Naval Shipbuilding Plan [11] outlines the Australian Government's vision to establish a long-term, continuous national naval shipbuilding enterprise, which represents the most significant national-building project Australia has ever undertaken. The Plan presents a way of how the Australian Government plans to build a strong, modern, and sustainable Australian naval shipbuilding industry. It provides the foundation for implementing the Government's unprecedented commitment to the greatest regeneration of Australian naval capability since the Second World War. At the same time, it will create a long-term, sustainable naval shipbuilding and ship sustainment capability that will serve their strategic and economic interests for many decades. The Plan demonstrates how Australia is looking to the future and 
sets out the Australian Government's concept to deliver and sustain modern, capable naval vessels, on time and budget, maximizing Australian industry involvement and contributing to a secure and prosperous future for their nation. In accordance with [9] the Federal Government is investing 90 billion $\mathrm{A} \$$ in continuous naval shipbuilding, a long-term plan to create economic growth and thousands of jobs for generations to come. The Government has already committed to the build of up to 21 Pacific patrol boats, 12 offshore patrol vessels, 9 future frigates, and 12 future submarines.

The Australian Government, before the commencement of execution of the Naval Shipbuilding Plan did important analyses, and one of them was prepared by RAND Corporation [10]. RAND's report showed that the Australian naval shipbuilding industry was not in good shape, and as a consequence of long underinvestment, the cost of building naval ships in Australia was almost $40 \%$ higher than in the USA or other nations. The Defense budget could not endure such a high premium, and at the same time deliver naval ships of required capabilities. RAND proposed to do reforms in Government that would cover changes in acquisition and contracting processes. Also, the industry needs to improve its productivity and workplace culture. The Government and industry should work together in partnership to deliver a more productive and cost-competitive industry. Report [10] proposed three options for the acquisition of naval ships: build ships in Australia, partially build and outfit ships in Australia, or build ships offshore. At the same time for each option, there were sub-options: MOTS (military off the shelf) and modified existing design. These options were proposed to suit any of them for building a certain class of a ship.

The Government has taken decisive action regarding the improvement of naval shipbuilding infrastructure and invested approximately 600 million $\mathrm{A} \$$ in two major shipyards in the period from 2017 to 2020. It was needed to deliver complex warships and submarines continuously. They have invested in science, technology, engineering, and mathematics programs and want to inspire young people to choose these pathways with confidence, setting them on a course of success in this industry. The Plan [11] will give competitive Australian businesses great opportunities to compete for Defense contracts and transfer of knowledge, technology, and skills to other areas of the economy, expand into new markets, and pursue export opportunities. This will drive innovation, industry competitiveness, create jobs, and accelerate the growth of Australia's advanced manufacturing sector.

Following [9] the Government is committed to investing in the skills and knowledge base of the Australian naval shipbuilding workforce that will increase in size and become sustainable. Although it is shipbuilders' responsibility to recruit and train the workforce, the Government will support these processes through coordination of workforce needs among projects and help ensure there is a sufficient number of skilled workers. There is an assessment that in the period up to 2030 there will be 3200 direct and 5000 additional indirect jobs in the naval shipbuilding industry. To facilitate these efforts, the Government established Naval Shipbuilding College. The College has been established to enable a coordinated, national approach to workforce development and acquiring skills across the national naval shipbuilding enterprise. Over the medium and longer-term, Australia's national education and training system can train the workforce required to support the continuous naval shipbuilding program.

Document [9] predicts that the Australian MoD needs skilled Australian Public Service (APS) staff to work with industry to build, test, and deliver ships and submarines. The majority of the Defense APS workforce growth is in engineering, logistics, procurement, contracting, and program/project management positions. Critical categories include communications and marine engineers and naval architects, and MoD faces the challenge of competing against the industry to recruit and retain its workforce in these specialties.

The status of naval project management in the Australian MoD is given through the example of the Sea 5000 Future Frigate program. Providing support to the acquisition of Australia's Sea 
5000 Future Frigate program RAND report [18] proposed to establish the Program office which represents the core of the government's role in an acquisition program. The Program office should include people with various skills and areas of expertise. It starts with a couple of people at the beginning of the program and grows as the program advances. Programs are successful if, among other important criteria, they have experienced and knowledgeable people in key management, supervision, and technical positions. In [18] it is assessed that it would be a big challenge for Australia to provide experienced program managers in future programs because there are a few opportunities for MoD personnel to gain that experience and expertise. It means that the availability of ready program managers may be very limited. Document [18], also foreseen that Australia may require assistance from the ship design and build organizations of allied countries for future programs. It can be concluded that the Australian MoD has a lot of challenges with regards to naval project management, and it will need many improvements to put it on the right path.

\subsection{New Zealand - NZL}

NZL as a nation with significant maritime responsibility was an interesting example to include in this analysis because of its maritime orientation and available references in the subject area. NZL defense policies and strategy related to the use of the Navy and the vision of their future development are described in the [12]. By this document, the maritime investment will focus on the patrol and sealift forces that will provide Defense Forces with the capability needed to meet future challenges. The major naval shipbuilding projects in the period from 2019 to 2030 are:

- Acquisition of Southern Ocean Patrol Vessel, introduction into service in 2027, estimated value 300-600 million NZ\$.

- Acquisition of a multirole sealift vessel, introduction into service in 2029, estimated value 1 billion NZ\$.

Investment decisions after 2030:

- Acquisition of two Offshore Patrol Vessel, introduction into service in 2032.

- The ANZAC frigates will be replaced with modern surface combatants that are planned for the mid-2030s.

- HMNZS Canterbury will be replaced in the mid-2030s.

- Replacement of HMNZS Manawauai in the mid-2030s.

In 2017 NZ MoD established a new arrangement of project governance which is presented in Fig. 3. The overall responsibility for the capability portfolio lies at the Capability Governance Group - CGG. Under CGG there is Capability Management Group-CMG that focuses on operational management activities, such as risk management, coordination of resources, achieving delivery outcomes, monitoring, and reporting. Project boards have been established for all capability projects. Their purpose is to support Integrated Project Teams - IPT regarding project risk and other issues. IPT's are responsible for defining, developing, and delivering military capability. Other details about the structure and functioning of project governance in the NZL MoD and Defense Forces can be seen in the [19]. IPT's structure and functions are presented in Fig. 4. 


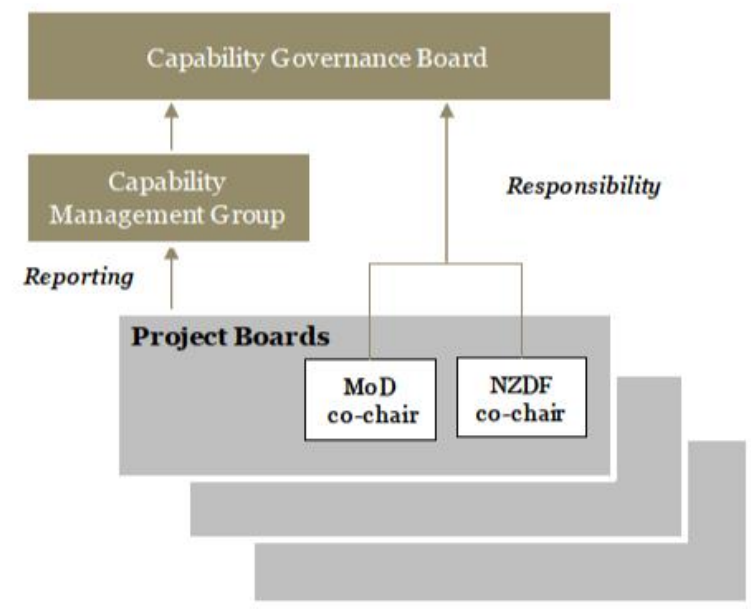

Fig. 3 NZL MoD Project governance, [19]

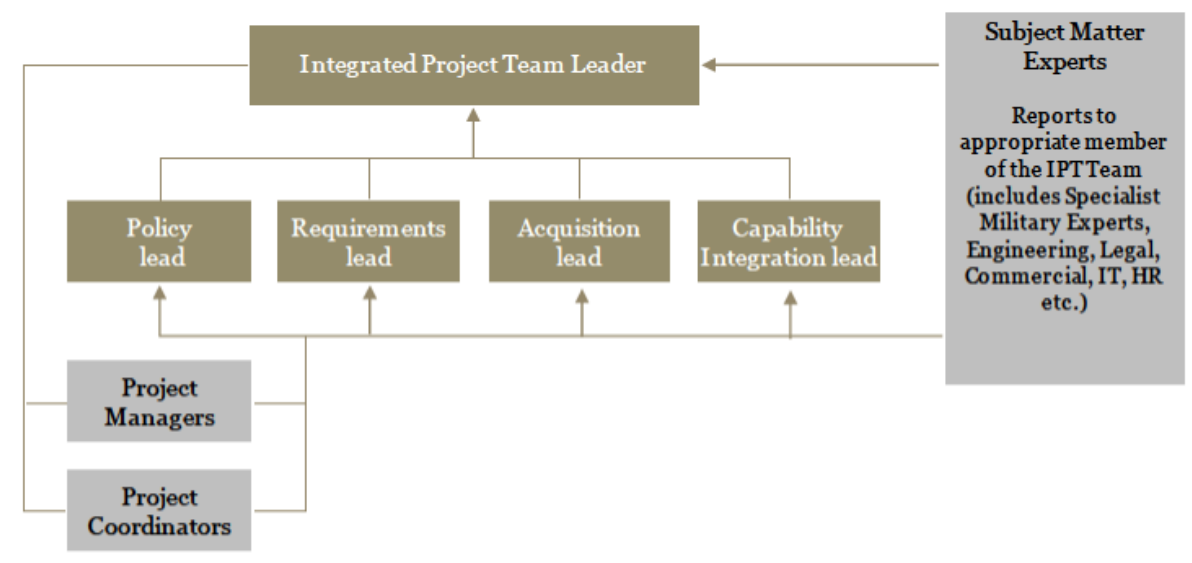

Fig. 4 IPT's structure and functions, [19]

Regarding the naval shipbuilding industry, it seems that NZ is currently focused on maintenance and upgrading capacities. Actual NZ naval fleet vessels were all built outside NZ. According to RNZN PLAN 2017 - 2025 [20], there are no indications that the present policy of building naval vessels outside NZ will be changed.

A similar situation is with personnel who mainly will work for maintenance facilities within the NZ Navy. There were no resources available dealing with investment in research and technology development in this area and it can be assessed that this investment if any will be focused on the naval maintenance capability.

\subsection{Republic of Croatia - HRV}

At present, there is no specific strategy for the development of naval shipbuilding in Croatia that would set the vision, main goals, and implementation plans in this area. There are developed plans within MoD generally related to strategic defense planning and the long-term development of the Armed Forces.

New knowledge and technologies in the production of equipment and goods related to maritime orientation, as well as the production of energy and food is a comparative advantage of Croatia's Mediterranean position, which provides numerous development opportunities that have not been sufficiently utilized so far [21]. 
Following [22] Croatian Navy has long term plan to equip with the following ships:
a. coastal patrol ships (4),
b. multi-purpose patrol ship (3),
c. anti-mine ships (used) (2).

At the end of the planning period (2015 - 2024), the project of a multi-purpose patrol ship will begin, as a carrier of the ability to fight against surface targets and elements of antisubmarine combat [22].

Croatia has a long tradition in merchant and naval shipbuilding and used to have 5 major shipyards. After the transition to democracy, all shipyards were privatized and the government left only a small percent of managing influence in some of them. The production capacity of the shipbuilding industry was halved, and the investment in their modernization was very limited. Currently, there is no shipyard in Croatia which is owned by the state for the production and maintaining of naval ships. During the mentioned transition period shipbuilding industry received some kind of reimbursement intending to reorganize and improve its businesses. At the moment shipyards that are involved in naval shipbuilding are on their own, and they invest in their modernization and future development. Also, there is no government plan which directly supports shipyards that are included in naval production. The only possible benefit from the state is the potential of getting a job through new orders of naval ships.

The workforce in Croatian shipyards depends on the demand for that kind of expertise, and shipyards support their development and recruitment. In other words, the workforce is on its own and depends on the situation in the market. There is no initiative within the government to invest in the research, development of new technologies in this area.

Project management of naval projects in the Croatian MoD recently got positive reorganization. It is based on project teams that are responsible for delivering project results and there is an institutional organization within the MoD that support and enhance project management processes and control and make important decisions regarding the project's status and execution. There is a lot of room for improvement in this area, as it is stated in [13], and it can be generalized for all navy and other projects within the MoD. It can be concluded that the mentioned changes are positive but to reach enhanced management of navy projects new investment are needed in education and preparation of future project managers for leading and participating in future projects.

\section{Analysis and trends in the management of naval projects}

The previous paragraph got a short overview of the project management of naval projects in different countries. There was an intention to research this area in other countries but there was a lack of usable information. The above analysis and management of the naval project are based on four criteria: strategic planning, industrial base, workforce, and project management organization. Table 1 shows a comparison of all five countries and assesses in terms of the four mentioned criteria. 
Table 1: Comparison and review of the management of naval projects in five countries

\begin{tabular}{|c|c|c|c|c|c|c|c|c|c|c|}
\hline \multirow[t]{2}{*}{\begin{tabular}{|l|}
$\begin{array}{l}\text { Review } \\
\text { criteria }\end{array}$ \\
Country \\
\end{tabular}} & \multicolumn{2}{|c|}{ Strategic planning } & \multicolumn{2}{|c|}{ Industrial base } & \multicolumn{3}{|c|}{ Workforce } & \multicolumn{3}{|c|}{$\begin{array}{c}\text { Project management } \\
\text { organization }\end{array}$} \\
\hline & \begin{tabular}{|c|}
$\begin{array}{c}\text { Strategy } \\
\text { exists }\end{array}$ \\
\end{tabular} & $\begin{array}{c}\text { Long term } \\
\text { plan } \\
\text { exists }\end{array}$ & \begin{tabular}{|c|} 
Investment \\
plan \\
exists
\end{tabular} & Challenges & \begin{tabular}{c|} 
Degree of \\
government \\
involvement
\end{tabular} & $\begin{array}{c}\text { Capacity } \\
\text { plan }\end{array}$ & $\begin{array}{l}\text { Focus } \\
\text { point }\end{array}$ & Maturity & $\begin{array}{c}\begin{array}{c}\text { Future } \\
\text { plans }\end{array} \\
\end{array}$ & $\begin{array}{l}\text { Compliance } \\
\text { to PM } \\
\text { standards }\end{array}$ \\
\hline USA & YES & $\begin{array}{c}\text { YES } \\
30 \text { years }\end{array}$ & YES & $\begin{array}{l}\text { Plan the } \\
\text { development } \\
\text { and } \\
\text { modernizatio } \\
\text { n in the naval } \\
\text { shipbuilding } \\
\text { sector } \\
\end{array}$ & HIGH & YES & $\begin{array}{c}\text { Shipyard } \\
\text { workforce }\end{array}$ & HIGH & YES & HIGH \\
\hline GBR & YES & $\begin{array}{c}\text { YES } \\
30 \text { years }\end{array}$ & YES & $\begin{array}{l}\text { Gov. } \\
\text { invested in } \\
\text { R\&D to } \\
\text { improve the } \\
\text { productivity } \\
\text { of the naval } \\
\text { shipbuilding } \\
\text { sector }\end{array}$ & HIGH & YES & $\begin{array}{l}\text { Technical } \\
\text { skill, } \\
\text { Education }\end{array}$ & HIGH & YES & $\mathrm{HIGH}$ \\
\hline AUS & $\mathrm{NO}$ & $\begin{array}{c}\text { YES } \\
30 \text { years }\end{array}$ & YES & $\begin{array}{l}\text { - Gov. has the } \\
\text { intention to } \\
\text { invest in } \\
\text { STEM and } \\
\text { modernizatio } \\
\text { n of naval } \\
\text { shipbuilding }\end{array}$ & HIGH & YES & $\begin{array}{c}\text { Workforce } \\
\text { development }\end{array}$ & MID & YES & MID \\
\hline NZL & NO & $\begin{array}{l}\text { YES } \\
8 \text { years }\end{array}$ & $\begin{array}{c}\text { YES } \\
\text { Development } \\
\text { of maintenance } \\
\text { capabilities }\end{array}$ & 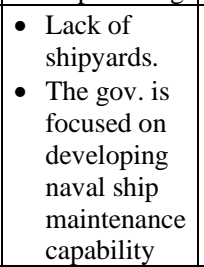 & MID & $\begin{array}{c}\text { YES } \\
\text { Maintenance }\end{array}$ & Maintenance & MID & YES & MID \\
\hline HRV & NO & $\begin{array}{c}\text { YES } \\
10 \text { years }\end{array}$ & NO & $\begin{array}{ll}\text { - } & \text { Bureaucracy } \\
\text { - } & \text { currently } \\
\text { gov. has no } \\
\text { intention of } \\
\text { investment in } \\
\text { research and } \\
\text { technology } \\
\text { in this } \\
\text { industrial } \\
\text { sector }\end{array}$ & LOW & NO & - & LOW & NO & LOW \\
\hline
\end{tabular}

\section{Conclusion}

This paper reviews the management of naval projects in five different countries. The general conclusions about the trends in the management of naval shipbuilding projects can be drawn based on the proposed four criteria i.e. strategic planning, industrial base, workforce, and project management organization. The conclusions apply although selected maritime countries vary in size, have a different influence in the world, and have a different history and culture.

It can be concluded that the advanced maritime countries (USA, GBR, AUS) have an intention to develop future navy fleets through:

- the strategy,

- the vision of the long term future,

- the goals that support the strategy,

- the activities and projects resulting from the strategy.

To accomplish it, the governments of these countries plan to invest in STEM, industrial shipbuilding base, and workforce development. All three countries have extensive experience 
and are leaders in naval shipbuilding projects, although AUS is about to improve this area in the future. To be successful in the management of naval shipbuilding projects it is necessary to satisfy all four of the above-proposed criteria, while the respective government has to manage and direct the related processes. Maritime countries such as Croatia that need to develop their navy, might benefit from the current and future patterns through subject developed countries. Due to lack of resources, it will be difficult to accomplish all four considered criteria, as it is demonstrated in NZL example where all efforts are focused on strategic planning and project management improvement without investment in naval shipbuilding capacities, while the criteria of the industrial base and the workforce are not to be implemented.

Although it is a big challenge to implement all four criteria, it may be recommended to HRV to consider the following measures:

- Develop a naval shipbuilding strategy that will provide a vision of future naval shipbuilding capacities.

- Improve strategic planning and increase the planning period to 30 years, instead of the current 10 years.

- Identify strategic goals, related projects, and activities supporting the strategic plan.

- All HRV shipyards that can produce naval ships should be government-supported in terms of research, implementation of new technologies, and modernization of naval shipbuilding.

- Enhance currently established project management organization and implement MoD structure based on project management organization with clear responsibilities for delivering projects satisfying the following: schedule, budget, required quality, and supervision standards.

- Develop the mid and long-term plans regarding support to the industry base improvement, and increase the competition in the naval shipbuilding sector.

\section{REFERENCES}

[1] M. E. Nissen and K. F. Snider, "U.S. defense acquisition research program," in PMi Research Conference 2000: Project Management Research at the Turn of the Millennium, Paris, 2000.

[2] Ö. Eren and F. Erenel, "The Applicability of Program Management Approach in the Defense Acquisition Projects in Order to Avoid Deviations," 2018.

[3] Defense Acquisition University, "Introduction to Defense Acquisition Management," Defense Acquisition University Press, Fort Belvoir, Virginia, Fort Belvoir, VA, USA, 2010.

[4] Defense Acquisition University, Joint Program Management Handbook, Fort Belvoir, VA, USA: Defense Acquisition University Press, Fort Belvoir, Virginia, 2004. https://doi.org/10.21236/ADA437767

[5] M. Schwartz, "Defense Acquisitions: How DOD Acquires Weapon Systems and Recent Efforts to Reform the Process," CRS, 2014.

[6] J. Riposo, M. McKernan and C. K. Duran, "Prolonged Cycle Tymes and Schedule Growth in Defense Acquisition," RAND National Defense Research Institute, 2014.

[7] UK Ministry of Defence, National Shipbuilding Strategy: The Future of naval Shipbuilding in the UK, London, UK: MoD, 2017.

[8] The United Kingdom's Naval Shipbuilding Industrial Base, RAND Corporation, 2005

[9] Australian Federal Government, "Naval Shipbuilding Strategic Workforce Discussion Paper," Australian Ministry of Defense, Canberra, Australia, 2019.

[10] RAND, "Australia's Naval Shipbuilding Enterprise Preparing for the 21 st Century," RAND, Santa Monica, California, USA, 2015.

[11] Australian Ministry of Defense, "Naval Shipbuilding Plan," Australian Ministry of Defense, Canberra, Australia, 2017.

[12] New Zealand MoD, "Defense Capability Plan 2019," The Ministry of Defence, New Zealand, Wellington 6144, New Zealand, 2019.

[13] A. Ljulj and D. Ćutić, "Project Management in Acquisition of the Croatian Coast Guard Patrol Ship," INTERDISCIPLINARY MANAGEMENT RESEARCH XVI, vol. 16, pp. 721-738, 7-9 May 2020. 
[14] United States Navy: Chief of Naval Operations 2.0, "A Design for Maintaining Maritime Superiority," US Navy, 2018.

[15] Congressional Research Service, "Navy Force Structure and Shipbuilding Background and Issues for Congress," CRS, 2020.

[16] US Department of Defense, Defense Acquisition Guidebook: Chapter1 program management, Fort Belvoir, VA 22060, USA: Defense Acquisition University, 2010.

[17] https://www.gov.uk/government/news/uk-shipbuilding-boosted-by-warship-procurement, last accessed 24.2.2021.

[18] J. F. Schank, M. V. Arena, K. N. Kramarck, G. T. Lee, J. Birkler, R. E. Murphy and R. Lough, "Naval Ship Acquisition on Course: Key Konsiderations for Managing Australia‘s Sea 5000 Future frigate program," RAND, 2014.

[19] New Zealand MoD, "Review of Defense Procurement," New Zealand Ministry of Defense, 2018.

[20] RNZN PLAN 2017 - 2025 To be a world-class Navy for a large maritime nation, NZBR 48, October 2017

[21] Croatian Ministry of Defense, "National Security Strategy," Official Gazette No. 151/14, Zagreb, Croatia, 2017.

[22] Croatian Ministry of Defense, "The Croatian Armed Forces Long-Term Development Plan 2015 - 2024," Croatian Ministry of Defense, Zagreb, Croatia, 2015.

Submitted: $\quad$ 11.01.2021. $\quad$ Ljulj Andrija, aljulj@morh.hr

\section{Accepted: $\quad$ 31.03.2021. Croatia}

Slapničar Vedran, vedran.slapnicar@fsb.hr

Faculty of Mechanical Engineering and Naval Architecture, Ivana Lučića 5, 10000 Zagreb, Croatia

Grubišić Izvor, izvor.grubisic@ @sb.hr

Faculty of Mechanical Engineering and Naval Architecture, Ivana Lučića 5, 10000 Zagreb, Croatia 